\title{
Composition and Significance of Bacterial Microbiota and Volatile Organic Compounds of Swiss-Dutch-Type Cheese as Determined by PCR-DGGE and HS-GC
}

\author{
Beata Nalepa ${ }^{1 *}$, Magdalena Anna Olszewska ${ }^{1}$, Lidia Hanna Markiewicz ${ }^{2}$, Marek Aljewicz ${ }^{3}$ \\ ${ }^{1}$ Department of Industrial and Food Microbiology, Faculty of Food Sciences, \\ University of Warmia and Mazury in Olsztyn, Pl. Cieszyński 1, 10-726 Olsztyn, Poland \\ ${ }^{2}$ Department of Immunology and Food Microbiology, Institute of Animal Reproduction and Food Research, \\ Polish Academy of Sciences, ul. Tuwima 10, 10-748 Olsztyn, Poland \\ ${ }^{3}$ Department of Dairy Science and Quality Management, Faculty of Food Sciences, \\ University of Warmia and Mazury in Olsztyn, ul. Oczapowskiego 7, 10-719 Olsztyn, Poland
}

Key words: Swiss-Dutch-type cheese, microbiota, VOCs, PCR-DGGE, HS-GC, seasonal variation

This study aimed to determine seasonal differences in the composition of bacterial microbiota and volatile organic compounds (VOCs) in SwissDutch-type cheese (manufactured between 2012 and 2014). Bacterial diversity and VOCs (acetaldehyde; ketones: acetone, diacetyl, acetoin; alcohols: methanol, ethanol; esters: ethyl acetate, ethyl propionate, ethyl butyrate; fatty acids: acetic acid, propionic acid, isobutyric acid, butyric acid, isovaleric acid, valeric acid, isocaproic acid, caproic acid, heptanoic acid) were determined by polymerase chain reaction - denaturing gradient gel electrophoresis (PCR-DGGE), and headspace gas chromatography (HS-GC), respectively. Season influenced the composition of both bacterial microbiota and VOCs in cheese. Counts of starter bacteria (Lactococcus, Leuconostoc and Propionibacterium - 6.51-7.14, 3.6-3.96 and 2.88-4.72 log CFU/g, respectively) were higher in the first year of the study, likewise these of the non-starter Lactobacillus (4.12-5.69 $\log \mathrm{CFU} / \mathrm{g}$ ). The total VOC content was substantially lower in the summer-autumn $2012(0.73228-3.34111 \mathrm{mg} / \mathrm{g})$ than in the other seasons $(63.28810-131.27690 \mathrm{mg} / \mathrm{g})$. Differences in bacterial microbiota and the VOC profiles were observed between cheeses manufactured in winter-spring and summer-autumn seasons. Winter- and spring-manufactured cheeses were also characterized by a lower number of bacterial species (average 8.7-10.5 species/sample) than the cheeses produced in the summer and in the autumn (average 10-13 species/sample). The results of the study indicate that the cheese-making process has to be continuously monitored to minimize differences across manufacturing seasons.

\section{INTRODUCTION}

Ripened cheeses are manufactured with the use of microorganisms, which results in the transformation of raw material (milk) into the final product (cheese). The processes that take place during cheese making and ripening are affected mainly by the composition and activity of microorganisms. Cheeses, including those that are manufactured industrially from pasteurized milk with starter cultures, are characterized by high microbial biodiversity because starter cultures (selected species of Lactococcus, Lactobacillus, and Propionibacterium) are always accompanied by other bacteria, including nonstarter lactic acid bacteria (NSLAB) such as Lactobacillus plantarum and $L$. brevis, fecal bacteria (coliforms, enterococci), sporeforming bacteria (Bacillus, Clostridium), and others [Johnson, 2017; Ogier et al., 2004; Ricciardi et al., 2015; Rehfeld et al., 2017; Santiago-Lopez et al., 2018]. All these microorganisms synthesize a wide range of metabolites, including volatile compounds (aldehydes, ketones, esters, fatty acids) that are

\footnotetext{
* Corresponding Author: Tel.: (48 89) 5234995;

E-mail: beata.nalepa@uwm.edu.pl (Dr. B. Nalepa) phy (HS-GC) [Ayad et al., 1999].

responsible for the flavor, aroma and consistency of cheese, and contribute to the development of desirable final product attributes [Felicio et al., 2016; Franciosi et al., 2009].

However, cheese production is a highly complex process; therefore, interdisciplinary methods are required to analyze the relationships between microorganisms, their metabolic activity, and changes in the physicochemical properties of cheese. Molecular biology methods and instrumental analytical techniques can be used to study these processes in greater detail. For instance, polymerase chain reaction denaturing gradient gel electrophoresis (PCR-DGGE) is one of such methods which supports the evaluation of various microbial genera and species, their semi-quantitative composition, changes over time or the presence of viable but nonculturable (VBNC) cells and cells that are suppressed by starter bacteria [Ercolini et al., 2001; Joux \& Lebaron, 2000]. In turn, the metabolic activity of cheese microbiota can be determined by analyzing the content of metabolites, such as volatile organic compounds (VOCs), by using chromatographic techniques, e.g., headspace gas chromatogra- 
Therefore, the aim of this study was to assess the diversity of bacterial microbiota by PCR-DGGE and to identify and quantify VOCs by HS-GC in Swiss-Dutch-type cheeses manufactured in different seasons. Seasonal differences in VOC profiles and the potential links between the identified microorganisms and the VOC profiles of the examined cheeses were determined as well.

\section{MATERIALS AND METHODS}

\section{Cheese manufacture and sampling}

Swiss-Dutch-type cheeses were manufactured and obtained from a dairy plant in the Region of Warmia and Mazury in the north-eastern Poland. The cheeses were produced from $10,000 \mathrm{~L}$ (each) of premium cow milk which was pasteurized $\left(72.5^{\circ} \mathrm{C}\right.$ for $15 \mathrm{~s}$ ) and standardized (to $3.0 \%$ fat), inoculated with calcium chloride, a coloring agent, rennet (Chymax, Ch. Hansen, Cząstków Mazowiecki, Poland), and a deepfrozen cheese starter (CSK food enrichment, Toruń, Poland). The applied starter was composed of Lactococcus lactis spp. lactis, Leuconostoc mesenteroides spp. cremoris (SLAB), and Propionibacterium freudenreichii spp. shermanii (PAB). The inoculum levels were $0.7 \%$ (by volume) for SLAB and $0.007 \%$ (by volume) for PAB. Every stage of the production process was consistent with industrial standards and followed the Swiss-Dutch-type cheese technology. After brining, $5 \mathrm{~kg}$ cheese blocks were wrapped in FCC type (Fesco Pack, Malbork, Poland) heat shrink, oxygen barrier bags and stored (ripened) under controlled conditions at $12^{\circ} \mathrm{C}$ for 10 days and then at $21^{\circ} \mathrm{C}$ for 42 days at $85 \%$ relative humidity. Cheese samples were collected over a period of two years between June 2012 and July 2014, and two cheese pieces of $0.5 \mathrm{~kg}$ each were sampled at one "time-point" (month). Three samples of each "time-point" cheese were taken in accordance with ISO 707:2008 [IDF 50:2008]. The samples for testing were packed in sterile bags. Cheeses manufactured between July and September were regarded as summer samples, cheeses produced in October-December - as autumn samples, cheeses produced in January-March - as winter samples, and cheeses produced in April-June - as spring samples.

\section{Chemical composition of cheeses}

Cheeses were subjected to chemical composition analyses to determine their sodium chloride, moisture, and fat contents. Salt content was determined according to ISO 5943:2006 [IDF 88:2006], moisture content was determined by oven drying at $102^{\circ} \mathrm{C}$ [AOAC $2005,926.08$ ], and fat content was determined according to ISO 3433:2008 [IDF 222:2008].

\section{Determination of the counts of selected bacterial groups by the culture-dependent method}

The counts of bacteria of the Lactobacillus, Lactococcus, Leuconostoc, Propionibacterium, Enterococcus, Staphylococcus, Clostridium, and Bacillus genera and of coliforms were determined by the standard plate count method on the appropriate culture media which are presented in Table 1. All media, except Reinforced Clostridial Medium (RCM), were supplied by Merck (Warsaw, Poland). RCM was supplied by Oxoid (Poznań, Poland).
TABLE 1. Culture media and incubation conditions applied in the study.

\begin{tabular}{l|c|c}
\hline Microorganism & Medium & $\begin{array}{c}\text { Incubation } \\
\text { conditions }\end{array}$ \\
\hline Lactococcus & M17 agar according to & $30^{\circ} \mathrm{C}, 48 \mathrm{~h}$ \\
& Terzaghi \& Sandine [1975] & \\
Leuconostoc & Sucrose agar: \\
& (sucrose $-50 \mathrm{~g} / \mathrm{L}$, \\
yeast extract $-10 \mathrm{~g} / \mathrm{L}$, \\
Propionibacterium & $30^{\circ} \mathrm{C}, 72 \mathrm{~h}$ \\
agar $-15 \mathrm{~g} / \mathrm{L} ; \mathrm{pH} 7.2-7.4)$ \\
Lactobacillus & Sodium lactate $(\mathrm{SLA})$ & $30^{\circ} \mathrm{C}, 72-96 \mathrm{~h}$, \\
& agar [Drinan \& Cogan, 1992] & anaerobic \\
Coliforms & Rogosa agar & $30^{\circ} \mathrm{C}, 48 \mathrm{~h}$, \\
Enterococcus & Violet Red Bile Lactose & anaerobic \\
Staphylococcus & (VRBL) agar & $37^{\circ} \mathrm{C}, 24-48 \mathrm{~h}$ \\
& Stanetz-Bartley agar & $37^{\circ} \mathrm{C}, 48 \mathrm{~h}$ \\
Clostridium & Rabbit plasma fibrinogen & $37^{\circ} \mathrm{C}, 48 \mathrm{~h}$ \\
Bacillus & (RPF) agar & $37^{\circ} \mathrm{C}, 48 \mathrm{~h}$, \\
\hline
\end{tabular}

Anaerobic conditions were obtained with the use of Anaerocult $\mathrm{C}$ bags (Merck, Warszawa, Poland).

\section{DNA isolation and polymerase chain reaction (PCR)}

Bacterial DNA was isolated directly from cheese samples with the Genomic Mini AX FOOD Kit (A@A Biotechnology, Gdańsk, Poland) in accordance with the manufacturer's instructions. The isolated DNA was stored at a temperature of $-80^{\circ} \mathrm{C}$ until further analysis. Amplification was carried out in the MJ Mini Gradient Thermal Cycler (Bio-Rad, Warszawa, Poland). The applied primers were U968-GC (5'-CGCCCGGGGCGCGCCCCGGGCGGGGCGGGGGCACGGGGGGAACGC

GAAGAACCTTAC-3') and L1401-r (5'-CGGTGTGTACAAGACCC-3') [Randazzo et al., 2010] which amplify the V6-V8 region of the 16S rRNA coding gene. The Master mix $(25 \mu \mathrm{L})$ consisted of $1 \times$ reaction PCR buffer $(20 \mathrm{mmol} / \mathrm{L}$ Tris-HCl, pH 8.4, $50 \mathrm{mmol} / \mathrm{L} \mathrm{KCl}, 3 \mathrm{mmol} / \mathrm{L} \mathrm{MgCl}_{2}$, $50 \mu \mathrm{mol} / \mathrm{L}$ deoxyribonucleotides (dNTPs), $5 \mathrm{pmol} / \mathrm{L}$ of each primer), 1.25 U Taq polymerase (all reagents were supplied by Thermo Fisher Scientific, Warsaw, Poland) and 10-40 ng of the DNA template. The PCR profile was as follows: initial denaturation at $94^{\circ} \mathrm{C}$ for $5 \mathrm{~min}$, followed by 35 cycles of: denaturation at $94^{\circ} \mathrm{C}$ for $30 \mathrm{~s}$, annealing at $56^{\circ} \mathrm{C}$ for $30 \mathrm{~s}$, and extension at $68^{\circ} \mathrm{C}$ for $40 \mathrm{~s}$. Final extension was carried out at $68^{\circ} \mathrm{C}$ for $7 \mathrm{~min}$ [Randazzo et al., 2010]. The presence of PCR products was analyzed by electrophoresis on $1 \%$ agarose gel in a $0.5 \times$ Tris-borate-EDTA buffer in the MultiSub Choice system (Clever Scientific Ltd., Rugby, UK).

\section{Denaturing gradient gel electrophoresis (DGGE)}

PCR products $(\sim 450 \mathrm{bp})$ were analyzed by denaturing gradient gel electrophoresis (DGGE) with urea and formamide (Sigma, Poznań, Poland) as denaturing agents. Electrophoresis was carried out in $8 \%$ polyacrylamide gel (acrylamide:bis-acrylamide, 37.5:1) (Sigma, Poznań, Poland) where the denaturing gradient was increased from $35 \%$ to $57.5 \%$. Electrophoresis was conducted in a $0.5 \times$ Tris-ace- 
tate-EDTA buffer (Sigma, Poznań, Poland) at $60^{\circ} \mathrm{C}$ and $85 \mathrm{~V}$ for $16 \mathrm{~h}$ [Randazzo et al., 2010] in the DCode Universal Mutation System (Bio-Rad, Warszawa, Poland). Gels were stained in SybrGreen I (1:10,000) (Sigma, Poznań, Poland) solution for $15 \mathrm{~min}$ and documented in G-Box (Syngen, Wrocław, Poland).

\section{Biological diversity of cheese microbiota}

DGGE band patterns of the analyzed cheeses were compared with the previously developed markers [Nalepa \& Markiewicz, 2017] composed of 24 reference strains: Propionibacterium freudenreichii ssp. shermanii DSM 4902, P. thoenii DSM 20276, Lactococcus lactis ssp. lactis DSM 4366, Leuconostoc mesenteroides DSM 20346, Lactobacillus acidophilus DSM 9126, L. plantarum ATCC 8014, L. brevis DSM 1267, L. casei ATCC 334, L. delbrueckii DSM 20080, L. fermentum DSM 200052, L. helveticus DSM 20075, Escherichia coli ATCC 8739, Enterobacter aerogenes ATCC 13048, E. cloacae ATCC 13047, Citrobacter freundii ATCC 8090, Enterococcus faecalis ATCC 29212, Bacillus subtilis ATCC 6051, Clostridium butyricum ATCC 10702, C. tyrobutyricum ATCC 2637, $C$. perfringens ATCC 13124, Listeria monocytogenes ATCC BAA751, Streptococcus thermophilus ATCC 19258, Staphylococcus xylosus ATCC 29971, and S. aureus ATCC 43300. Bacterial species were identified and given a score of 0 to 4 points based on band brightness. Electrophorograms were subjected to 1D analysis in the Doc-It LS Image Analysis Software (UVP Ltd., Cambridge, UK). The results were used to calculate the Shannon-Wiener diversity index with the use of the following formula:

$$
H^{\prime}=-\sum_{i=1}^{S} p_{i} \ln p_{i}
$$

[Sienkiewicz, 2010],

where $p_{\mathrm{i}}$ is the proportion of individuals found in species $i$.

\section{Analysis of volatile organic compounds (VOCs) by headspace gas chromatography}

Selected volatile compounds, including aldehydes (acetaldehyde), ketones (acetone, diacetyl, acetoin), alcohols (methanol, ethanol), esters (ethyl acetate, ethyl propionate, ethyl butyrate), and fatty acids $\mathrm{C}_{2}-\mathrm{C}_{7}$ (acetic acid, propionic acid, isobutyric acid, butyric acid, isovaleric acid, valeric acid, isocaproic acid, caproic acid, heptanoic acid), were identified by headspace gas chromatography (HS-GC) in the Headspace Turbomatrix 40 autosampler (Perkin Elmer, Waltham, USA) and the Clarus 500 gas chromatography system (Perkin Elmer, Waltham, USA) with a flame ionization detector (FID). The content of metabolites was expressed in $\mathrm{mg} / \mathrm{g}$. The chromatograph was calibrated for quantitative identification of selected metabolites based on external standards. Calibration curves were generated for every compound within the relevant concentration range. Equilibrium between the sample and the headspace was achieved by heating $3 \mathrm{~g}$ of cheese to $70^{\circ} \mathrm{C}$ for $40 \mathrm{~min}$ in tightly closed $22 \mathrm{~mL}$ vials. The sample was pressurized for $1 \mathrm{~min}$ and injected into the column (split ratio of $2: 1$ ) within $0.08 \mathrm{~min}$. Needle and transfer line temperature was $100^{\circ} \mathrm{C}$ and $120^{\circ} \mathrm{C}$, respectively. Volatile compounds were separated in an HP-INNOWAX (Agilent Technologies, Palo Alto, USA) column $(60 \mathrm{~m} \times 1.00 \mu \mathrm{m} \times 0.537 \mathrm{~mm})$ with the following temperature gradient: $40^{\circ} \mathrm{C}(5 \mathrm{~min}) \rightarrow \Delta \mathrm{T} 10^{\circ} \mathrm{C} /$ $\min \rightarrow 220^{\circ} \mathrm{C}$ (5 min.). Injector and FID temperature was $230^{\circ} \mathrm{C}$. The carrier gases were: helium $(5 \mathrm{~mL} / \mathrm{min})$, synthetic air $(400 \mathrm{~mL} / \mathrm{min})$, and hydrogen $(40 \mathrm{~mL} / \mathrm{min})$. Column pressure was $130 \mathrm{kPa}$.

\section{Statistical analysis}

The results of chemical composition and bacterial counts were verified for normal distribution and homogeneity of variance. The significance of differences between means was analyzed by Duncan's test $(\mathrm{p} \leq 0.05)$. The interactions between factors were determined by ANOVA for the completely randomized design. The results of PCR-DGGE profile analyses were expressed as arithmetic means for each month (24 timepoints). To determine whether the presence of the identified VOCs in Swiss-Dutch-type cheeses was correlated with season, principal component analysis (PCA) was performed with VOCs as quantitative variables and seasons as qualitative variables. Before, VOCs were subjected to hierarchical cluster analysis (HCA) [Granato et al., 2018] for assessment of similarity between the identified VOCs. Pearson's correlation coefficients (r) were calculated to determine whether the VOCs were associated with the microorganisms detected in cheese samples $(\mathrm{p} \leq 0.05)$. Data were processed in the Statistica v. 12.5 software (StatSoft Polska, Kraków, Poland).

\section{RESULTS AND DISCUSSION}

\section{Chemical composition and microbiota of Swiss-Dutch- type cheese}

The average water content of all cheeses was $42.65 \mathrm{~g} / 100 \mathrm{~g}$. Water content was the highest $(43.46 \mathrm{~g} / 100 \mathrm{~g})$ in cheeses produced in 2012 and the lowest $(42.06 \mathrm{~g} / 100 \mathrm{~g})$ in cheeses produced in 2013. There were no significant $(p>0.05)$ differences among cheeses manufactured in different seasons or years. The fat content of the cheeses produced between 2012 and 2014 was comparable $(\mathrm{p}>0.05)$ and ranged from $25.67 \mathrm{~g} / 100 \mathrm{~g}$ to $28.17 \mathrm{~g} / 100 \mathrm{~g}$. The average content of sodium chloride in cheeses produced in 2012 was $1.58 \mathrm{~g} / 100 \mathrm{~g}$ and did not differ significantly from that noted in the cheeses produced in $2013(1.72 \mathrm{~g} / 100 \mathrm{~g})$ and $2014(1.51 \mathrm{~g} / 100 \mathrm{~g})$ (Table 2).

The counts of the determined bacterial groups are presented in Table 3. Starter bacteria (Lactococcus, Leuconostoc, and Propionobacterium) were detected in cheese samples in all analyzed seasons. The most prevalent bacterial group was Lactococcus, and its counts ranged from 5.45 to $7.14 \mathrm{log}$ $\mathrm{CFU} / \mathrm{g}$ of cheese. Leuconostoc and Propionibacterium counts were lower at 1.20-3.98 log CFU/g and 0.67-4.72 log $\mathrm{CFU} / \mathrm{g}$, respectively. These bacteria were more abundant in the cheese samples collected in all seasons of the first year of the experiment (Table 3). Cheese samples from all seasons contained also bacteria of the genera Lactobacillus (4.12 to $5.69 \log \mathrm{CFU} / \mathrm{g}$ ) and Bacillus (3.30 to $4.18 \log \mathrm{CFU} / \mathrm{g}$ ). The counts of the remaining bacterial groups (coliforms, Enterococcus, Staphylococcus, Clostridium) were considerably more varied across seasons, ranging from $<1 \log \mathrm{CFU} / \mathrm{g}$ (Enterococcus and Staphylococcus in the winter of 2012, Clostridium in the spring of 2013, coliforms in the spring of 2014) 
TABLE 2. Chemical composition (g/100 g) of Swiss-Dutch-type cheeses manufactured between 2012 and 2014.

\begin{tabular}{l|rr|c|c|c|c|c|c}
\hline \multirow{2}{*}{$\begin{array}{l}\text { Chemical } \\
\text { composition }\end{array}$} & \multicolumn{2}{|c|}{2012} & \multicolumn{2}{c|}{2013} & \multicolumn{2}{c}{2014} \\
\cline { 2 - 10 } & Summer & Autumn & Winter & Spring & Summer & Autumn & Winter & Spring \\
\hline Water & $43.92 \pm 0.48$ & $43.00 \pm 0.40$ & $41.72 \pm 0.37$ & $41.59 \pm 0.31$ & $42.97 \pm 0.67$ & $41.95 \pm 0.72$ & $43.29 \pm 0.43$ & $42.78 \pm 0.33$ \\
Fat & $26.50 \pm 0.50$ & $27.67 \pm 0.29$ & $26.00 \pm 0.50$ & $26.17 \pm 0.58$ & $27.50 \pm 0.50$ & $27.33 \pm 0.29$ & $25.67 \pm 0.29$ & $28.17 \pm 0.29$ \\
Sodium chlorine & $1.69 \pm 0.01$ & $1.47 \pm 0.07$ & $1.48 \pm 0.03$ & $1.48 \pm 0.04$ & $1.62 \pm 0.03$ & $1.49 \pm 0.05$ & $1.50 \pm 0.03$ & $1.52 \pm 0.05$ \\
\hline
\end{tabular}

The presented values are means \pm standard deviation for $n=3$ ( 3 time-points) in each season.

TABLE 3. Microbial counts (log CFU/g) in Swiss-Dutch-type cheeses manufactured between 2012 and 2014.

\begin{tabular}{l|c|c|c|c|c|c|c|c}
\hline \multirow{2}{*}{$\begin{array}{l}\text { Genera/group } \\
\text { of microorganisms }\end{array}$} & \multicolumn{2}{|c|}{2012} & \multicolumn{4}{c}{2013} & \multicolumn{2}{c}{2014} \\
\cline { 2 - 9 } & Summer & Autumn & Winter & Spring & Summer & Autumn & Winter & Spring \\
\hline Lactococcus & $6.51 \pm 0.39^{\mathrm{ab}}$ & $7.01 \pm 0.13^{\mathrm{a}}$ & $7.14 \pm 0.14^{\mathrm{a}}$ & $6.79 \pm 0.70^{\mathrm{ab}}$ & $5.51 \pm 0.55^{\mathrm{ab}}$ & $6.28 \pm 0.34^{\mathrm{ab}}$ & $5.45 \pm 0.29^{\mathrm{a}}$ & $6.31 \pm 0.39^{\mathrm{ab}}$ \\
Leuconostoc & $3.62 \pm 0.49^{\mathrm{ab}}$ & $3.60 \pm 0.19^{\mathrm{ab}}$ & $3.98 \pm 0.36^{\mathrm{bc}}$ & $3.96 \pm 0.66^{\mathrm{abd}}$ & $1.58 \pm 0.65^{\mathrm{cd}}$ & $3.02 \pm 0.40^{\mathrm{abcd}}$ & $1.20 \pm 0.64^{\mathrm{c}}$ & $3.26 \pm 0.73^{\mathrm{acd}}$ \\
Propionibacterium & $2.88 \pm 0.54^{\mathrm{ab}}$ & $2.75 \pm 0.85^{\mathrm{ab}}$ & $4.72 \pm 0.25^{\mathrm{c}}$ & $3.70 \pm 0.23^{\mathrm{bc}}$ & $1.47 \pm 0.54^{\mathrm{a}}$ & $2.08 \pm 0.52^{\mathrm{ab}}$ & $0.67 \pm 0.50^{\mathrm{a}}$ & $2.86 \pm 0.52^{\mathrm{ab}}$ \\
Lactobacillus & $5.08 \pm 0.41^{\mathrm{abc}}$ & $5.64 \pm 0.21^{\mathrm{c}}$ & $5.69 \pm 0.23^{\mathrm{bc}}$ & $4.12 \pm 0.52^{\mathrm{ab}}$ & $4.35 \pm 0.45^{\mathrm{abc}}$ & $4.98 \pm 0.13^{\mathrm{abc}}$ & $4.48 \pm 0.17^{\mathrm{a}}$ & $4.79 \pm 0.49^{\mathrm{abc}}$ \\
Coliforms & $1.31 \pm 0.76^{\mathrm{ab}}$ & $3.00 \pm 0.57^{\mathrm{abc}}$ & $3.15 \pm 0.71^{\mathrm{ab}}$ & $3.71 \pm 0.29^{\mathrm{bc}}$ & $3.18 \pm 0.58^{\mathrm{ab}}$ & $3.13 \pm 0.11^{\mathrm{ab}}$ & $1.50 \pm 0.95^{\mathrm{abc}}$ & $<1.00 \pm 0.00^{\mathrm{c}}$ \\
Enterococcus & $2.77 \pm 0.67^{\mathrm{a}}$ & $3.04 \pm 0.80^{\mathrm{a}}$ & $<1.00 \pm 0.00^{\mathrm{a}}$ & $1.41 \pm 0.76^{\mathrm{a}}$ & $2.25 \pm 0.60^{\mathrm{a}}$ & $2.76 \pm 0.70^{\mathrm{a}}$ & $2.13 \pm 0.8^{\mathrm{a}}$ & $0.72 \pm 0.50^{\mathrm{a}}$ \\
Staphylococcus & $1.00 \pm 0.63^{\mathrm{a}}$ & $0.75 \pm 0.62^{\mathrm{a}}$ & $<1.00 \pm 0.00^{\mathrm{a}}$ & $1.32 \pm 0.74^{\mathrm{a}}$ & $2.69 \pm 0.61^{\mathrm{a}}$ & $3.65 \pm 0.37^{\mathrm{a}}$ & $0.95 \pm 0.67^{\mathrm{a}}$ & $0.85 \pm 0.74^{\mathrm{a}}$ \\
Clostridium & $2.22 \pm 0.80^{\mathrm{ab}}$ & $4.02 \pm 0.68^{\mathrm{a}}$ & $3.74 \pm 0.83^{\mathrm{ab}}$ & $<1.00 \pm 0.69^{\mathrm{b}}$ & $2.77 \pm 0.74^{\mathrm{ab}}$ & $3.70 \pm 0.65^{\mathrm{a}}$ & $3.92 \pm 0.67^{\mathrm{a}}$ & $3.03 \pm 0.27^{\mathrm{a}}$ \\
Bacillus & $3.74 \pm 0.20^{\mathrm{a}}$ & $3.69 \pm 0.06^{\mathrm{a}}$ & $3.88 \pm 0.18^{\mathrm{a}}$ & $3.54 \pm 0.26^{\mathrm{a}}$ & $3.80 \pm 0.19^{\mathrm{a}}$ & $3.89 \pm 0.26^{\mathrm{a}}$ & $3.30 \pm 0.19^{\mathrm{a}}$ & $4.18 \pm 0.37^{\mathrm{a}}$ \\
\hline
\end{tabular}

The presented values are means \pm standard deviation for $n=3$ in seasons. Mean values in rows with different superscript letters are significantly different $(\mathrm{p} \leq 0.05)$. Limit of detection $=1 \log \mathrm{CFU} / \mathrm{g}$.

to $4.02 \log \mathrm{CFU} / \mathrm{g}$ (Clostridium in the autumn of 2012) (Table 3). Similar Enterobacteriaceae and Staphylococcus counts in cheese were reported by Frece et al. [2016].

Bacterial species were identified based on DGGE bands which were obtained with the use of the developed markers [Nalepa \& Markiewicz, 2017] and given a score of 0 to 4 based on their brightness (Figure 1). PCR-DGGE is a semiquantitative method where the quantity of target DNA corresponding to the number of cells from which it was isolated is positively correlated with the number of amplicons and the brightness of DGGE bands. The band brightness of starter cultures (L. lactis, L. mesenteroides, and P. freudenreichii) scored 0 to 3 points in the first year (summer 2012 - spring 2013), and 1 to 4 points in the second year (summer 2013 - spring 2014) of the experiment (Figure 1). The most prevalent nonstarter bacteria (lactic acid bacteria and propionic acid bacteria) were $L$. brevis and $L$. fermentum, but they showed in the cheese samples randomly. P. thoenii and L. acidophilus were found mainly in the samples collected between the summer of 2013 and the spring of 2014. L. delbrueckii, $L$. helveticus and $L$. casei were not observed in winter and spring samples, regardless of the experimental year. Among sporeforming bacteria, the most predominant microorganisms were $B$. subtilis and $C$. tyrobutyricum, where $B$. subtilis was more prevalent and was identified in all samples collected between the summer of 2013 and the spring of 2014. E. coli and E. faecalis were more prevalent in the samples collected between the summer of 2013 and the spring of 2014 than in the remaining months of the study (Figure 1).

In the group of the 24 analyzed species, 6 to 17 bacterial species were detected in the analyzed cheese samples (Table 4). A smaller number of bacterial species was identified in the first year: 11 in the summer of 2012, 11.3 in the autumn of 2012, 8.7 in the winter of 2013, and 10.5 in the spring of 2013 on average. In the second year of the study, the number of identified species was higher reaching 13 in the summer-autumn of 2013 and 10 in the winter of 2013 - spring of 2014 on average. Considerable variations in the number of species were observed between the months/seasons of both years. The number of bacterial species was higher in the samples collected in summer-autumn than in winter-spring periods. Starter bacteria were identified in all samples, excluding the sample from the autumn of 2012 where $L$. lactis was not identified (Figure 1). The most prevalent other bacteria were $L$. brevis and B. subtilis which were present in 17 samples (70.8\%) (Table 4), followed by C. tyrobutyricum which was found in 15 samples (62.5\%). L. fermentum, E. coli, and $S$. thermophilus/S. xylosus were detected in 14 samples (58.3\%), P. thoenii and L. acidophilus were noted in 12 samples (50.0\%), and $L$. casei and $E$. faecalis were found in 11 samples (45.8\%).

DGGE band patterns were also used in 1D analysis and to determine the Shannon-Wiener diversity index $\left(\mathrm{H}^{\prime}\right)$. 


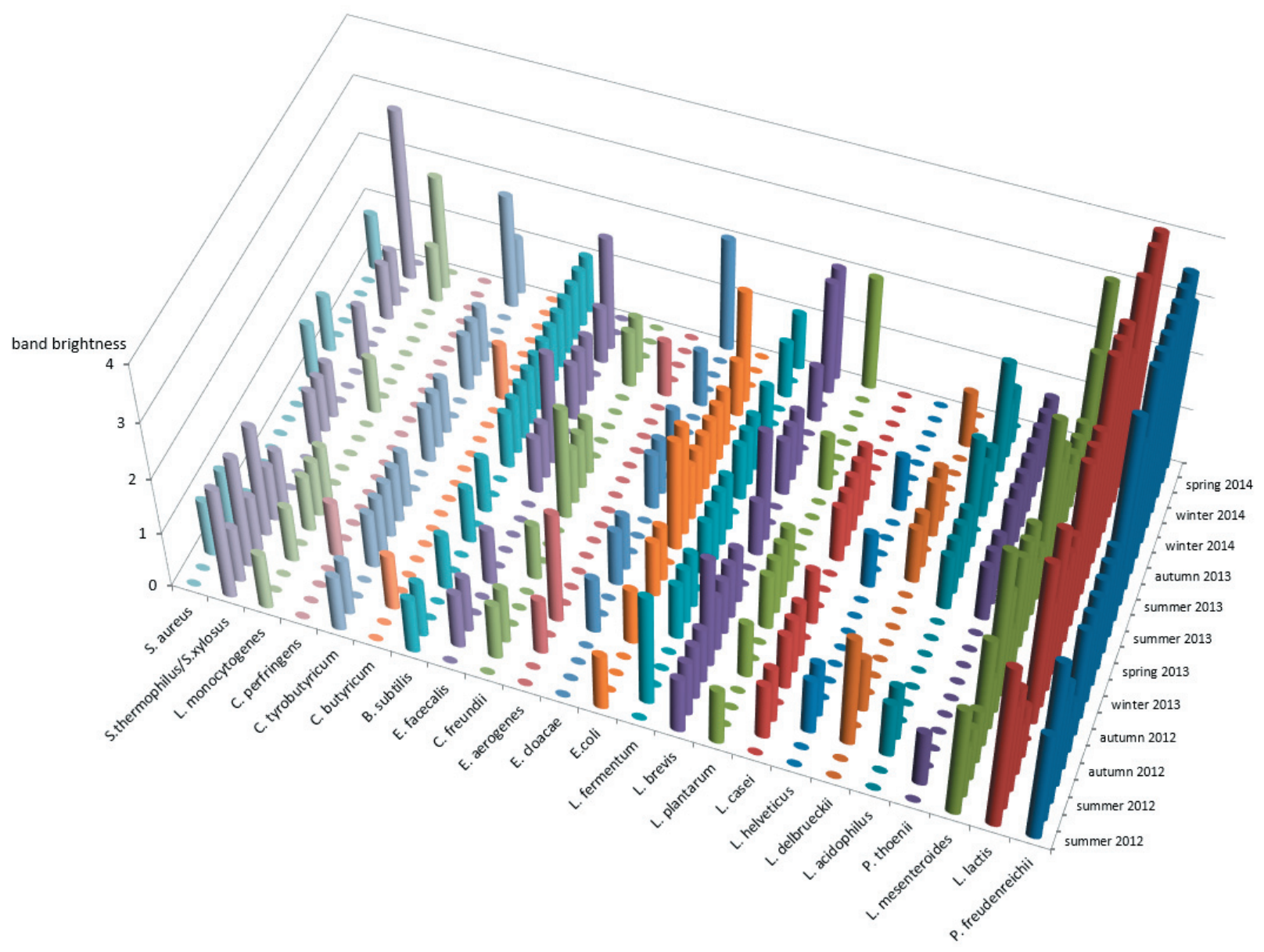

FIGURE 1. The identified microorganisms and relative band brightness on a scale of 0 to 4, determined in the PCR-DGGE assay of Swiss-Dutch-type cheeses manufactured between 2012 and 2014.

The values of H' ranged from 1.6704 in cheeses with 6 bacterial species to 2.9779 in cheeses with 17 bacterial species (data not shown). The evaluated cheeses were characterized by high bacterial diversity and contained from 3 to 14 bacterial species in addition to starter cultures (P. freudenreichii, $L$. lactis, L. mesenteroides).

The sensory attributes of ripened cheeses, produced both traditionally and industrially, are determined by numerous factors, in particular by the qualitative and quantitative composition of microbiota, its physiological status and metabolic activity [Smit et al., 2005]. For this reason, the microbiome of dairy raw materials and cheeses has to be monitored throughout the production process. Molecular biology methods, such as random amplified polymorphic DNA (RAPD), restriction fragment length polymorphism (RFLP), denaturing gradient gel electrophoresis (DGGE), temporal temperature gradient gel electrophoresis (TTGE) or next-generation sequencing (NGS), have been used by many authors to evaluate microbial communities in raw milk and cheeses [Alegría et al., 2009; Duru et al., 2018; Ercolini et al., 2001; Gala et al., 2008; Mangia et al., 2016; Porcellato \& Skeie, 2016; Randazzo et al., 2006; Skelin et al., 2012]. Most of these studies analyzed the microbiome composition of traditional cheeses produced in the Mediterranean region from unpasteurized milk and without starter cultures. Thermophilic species of lactic acid bacteria, such as $S$. thermophilus, S. macedonicus, $L$. helveticus and $L$. delbrueckii, are more frequently encountered in warmer regions of the southern Europe [Alegría et al., 2009; Franciosi et al., 2009]. In our study, L. helveticus and $L$. delbrueckii were identified only in the warmest seasons (summer-autumn) and were never observed in cold seasons (winter-spring), regardless of the year. Seasonal variations in the counts of mesophilic and thermophilic LAB were also reported in Perocino del Poro cheese [Caridi et al., 2003] where mesophilic bacteria were more abundant in spring, and thermophilic bacteria - in summer. These results indicate that the manufacturing season could influence the growth of microbiota and, consequently, the quality of the final product. In other studies, ripened cheeses were found to contain mesophilic bacteria including $L$. lactis, $L$. garvieae, L. mesenteroides, $L$. casei, $L$. paracasei, $L$. plantarum, and $L$. brevis, but also enterococci (E. faecalis, E. faecium, and E. hirae), Gramnegative bacteria (E. coli, Enterobacter spp., and Hafnia alvei), and staphylococci (S. saprophyticus and S. equorum) [Abriouel et al., 2008; Ercolini et al., 2001; Flórez \& Mayo, 2006; Marino et al., 2003]. Randazzo et al. [2006] demonstrated that traditional cheeses made from raw milk without starter cultures were characterized by greater microbiological diversity than cheeses manufactured with starter cultures, where a predominance of starter culture species was reported. In our study, 
TABLE 4. The number of bacterial species at different times of the year and the prevalence (\%) of bacterial species in Swiss-Dutch-type cheeses manufactured between 2012 and 2014.

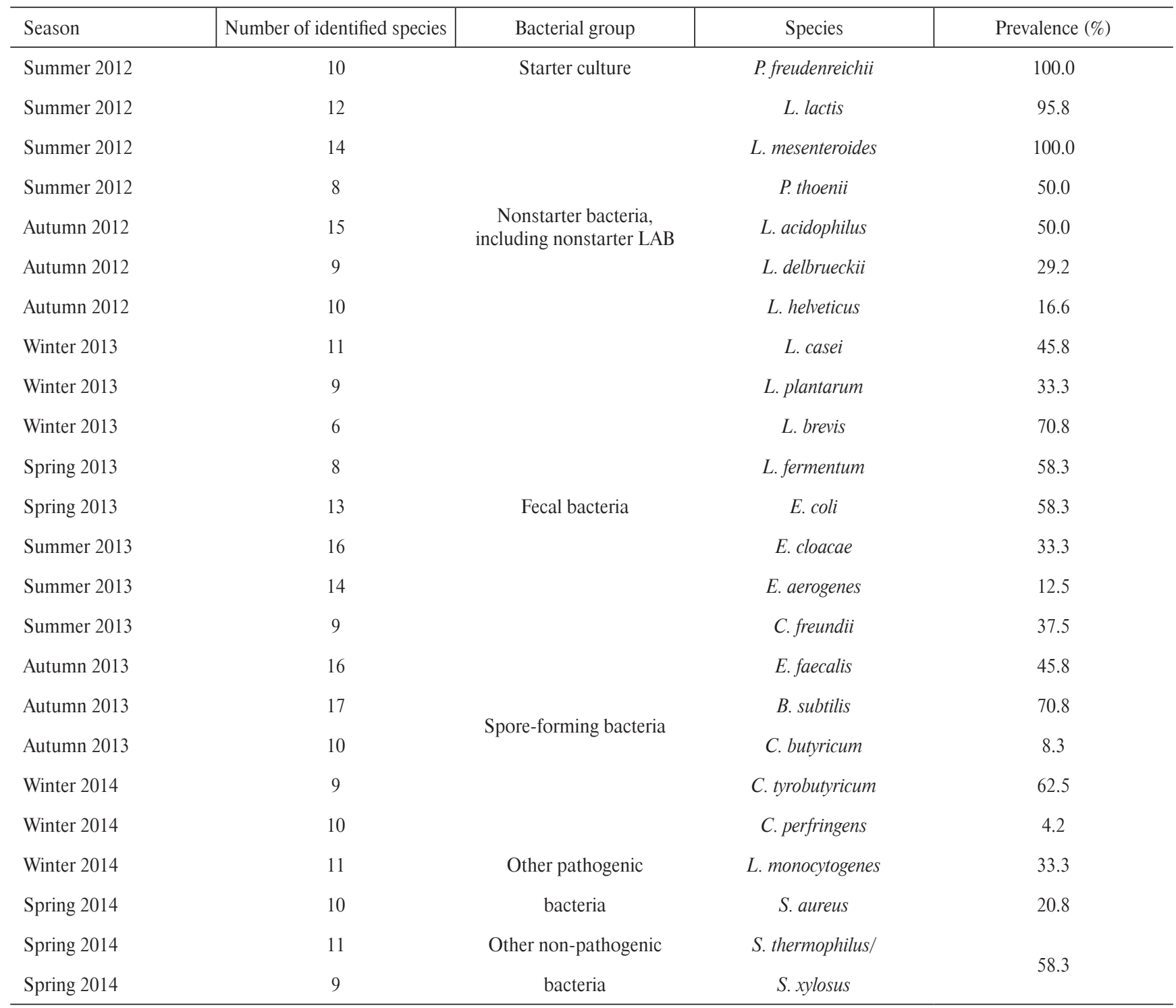

starter culture bacteria (L. lactis, L. mesenteroides, P. freudenreichii) were also most abundant in the analyzed cheeses. In DGGE profiles, the brightest bands corresponded to starter culture species, whereas the bands corresponding to other bacteria were less bright. The results of quantitative analyses revealed that starter culture bacteria were more prevalent than other bacteria (Figure 2 and Table 3). Duru et al. [2018] relied on next-generation sequencing (NGS) to demonstrate a predominance of Lactococcus, Lactobacillus, and Propionibacterium starter cultures which accounted for $80-82 \%$ of all reads in industrially manufactured Swiss-type cheese. In industrially produced Dutch-type cheese, starter bacteria (Lactococcus, Leuconostoc, and Lactobacillus) also accounted for more than $99 \%$ of the bacterial community in the NGS assay conducted by Porcellato \& Skeie [2016]. However, the production of cheese from pasteurized milk with the addition of starter cultures does not guarantee the growth of starter bacteria only, but NSLAB may also grow and be active. Lindberg et al. [1996] and Jordan \& Cogan [1993] identified
Lactobacillus paracasei, L. casei, and L. plantarum nonstarter bacteria in Swedish and Norwegian cheeses produced with the addition of Lactococcus and Leuconostoc starter cultures. In our study, the most prevalent NSLAB were $L$. brevis and $L$. fermentum, whereas L. casei/L. paracasei and thermophilic $L$. delbrueckii and L. helveticus were identified only in the summer and autumn. The analyzed cheeses also frequently contained spore-forming bacteria $B$. subtilis and $C$. tyrobutyricum. Klijn et al. [1995] demonstrated that the late-blowing defect in cheese was caused mainly by $C$. tyrobutyricum and butyric acid, its main fermentation product, in quantities greater than $100 \mathrm{mg} / \mathrm{kg}$. The natural environment and silage are the main sources of spore-forming bacteria that can lead to spoilage when transferred to raw milk and the cheese matrix.

\section{The VOC content of Swiss-Dutch-type cheese}

The content of selected volatile compounds (aldehydes, alcohols, esters, ketones, and fatty acids $\mathrm{C}_{2}-\mathrm{C}_{7}$ ) in the examined cheeses is presented in Table 5. Considerable differences 
TABLE 5. The content of volatile organic compounds (VOCs) (mg/g) in Swiss-Dutch-type cheeses manufactured between 2012 and 2014.

\begin{tabular}{|c|c|c|c|c|c|c|}
\hline Season & Aldehydes & Alcohols & Esters & Ketones & Fatty acids & Total \\
\hline Summer 2012 & 0.00048 & 0.36485 & - & 0.13640 & 0.23643 & 0.73817 \\
\hline Summer 2012 & 0.00138 & 0.00842 & - & 0.17972 & 0.54277 & 0.73228 \\
\hline Summer 2012 & 0.00060 & 0.17595 & 0.000025 & 0.10961 & 1.79419 & 2.08038 \\
\hline Summer 2012 & 0.00021 & 0.10131 & - & 0.09144 & 1.42441 & 1.61738 \\
\hline Autumn 2012 & 0.00055 & 0.09510 & - & 0.23241 & 2.39689 & 2.72495 \\
\hline Autumn 2012 & 0.00069 & 0.12584 & - & 0.15029 & 3.06430 & 3.34111 \\
\hline Autumn 2012 & 0.00019 & 0.05991 & - & 0.07645 & 2.47629 & 2.61284 \\
\hline Winter 2013 & 0.04798 & 2.56398 & 0.09433 & 0.00348 & 74.81968 & 77.52943 \\
\hline Winter 2013 & 0.00025 & 2.37653 & 0.10095 & 0.00733 & 7.37763 & 9.86268 \\
\hline Winter 2013 & 0.05265 & 2.38913 & 0.21640 & 0.00375 & 74.23943 & 76.90135 \\
\hline Spring 2013 & 0.04455 & 2.92663 & 0.15565 & 0.00310 & 60.15818 & 63.28810 \\
\hline Spring 2013 & 0.05028 & 2.58768 & 0.21038 & 0.00458 & 120.03033 & 122.88323 \\
\hline Summer 2013 & 0.05385 & 2.42525 & 0.24041 & 0.00536 & 111.08645 & 113.81133 \\
\hline Summer 2013 & 0.05588 & 3.03558 & 0.24185 & 0.00860 & 127.93500 & 131.27690 \\
\hline Summer 2013 & 0.00045 & 4.65645 & 0.20115 & 0.00775 & 21.41735 & 26.28315 \\
\hline Autumn 2013 & 0.04420 & - & 0.00080 & - & 89.18433 & 89.22933 \\
\hline Autumn 2013 & 0.04820 & 2.37845 & 0.09713 & 0.00588 & 75.83090 & 78.36055 \\
\hline Autumn 2013 & 0.05385 & 2.39680 & 0.09740 & 0.00603 & 65.49263 & 68.04670 \\
\hline Winter 2014 & 0.04351 & 0.63736 & 0.09884 & 0.00464 & 95.75041 & 96.53476 \\
\hline Winter 2014 & 0.03669 & 1.78571 & 0.09324 & 0.00415 & 89.19380 & 91.11359 \\
\hline Winter 2014 & 0.03069 & 1.73941 & 0.10704 & 0.00345 & 84.79109 & 86.67168 \\
\hline Spring 2014 & 0.02041 & 1.32240 & 0.11075 & 0.00293 & 86.83456 & 88.29105 \\
\hline Spring 2014 & 0.02810 & 1.81126 & 0.17619 & 0.00141 & 84.25300 & 86.26996 \\
\hline Spring 2014 & 0.04028 & 1.22004 & 0.08508 & 0.01268 & 72.45116 & 73.80923 \\
\hline
\end{tabular}

Aldehydes: acetaldehyde; Alcohols: methanol, ethanol; Esters: ethyl acetate, ethyl propionate, ethyl butyrate; Ketones: acetone, diacetyl, acetoin; Fatty acids: acetic acid, propionic acid, isobutyric acid, butyric acid, isovaleric acid, valeric acid, isocaproic acid, caproic acid, heptanoic acid.

in VOC content were observed between seasons. In the summer-autumn of 2012, the total VOC content of the evaluated samples ranged from 0.73228 to $3.34111 \mathrm{mg} / \mathrm{g}$ of cheese and was substantially lower than in the winter of 2013-spring of 2014 when it ranged from 63.28810 to $131.27690 \mathrm{mg} / \mathrm{g}$. Two exceptions were noted in the second year of the study (26.28315 mg/g in the summer of 2013 and $9.86267 \mathrm{mg} / \mathrm{g}$ in the winter of 2013) when VOC concentrations were lower than in the remaining samples from the corresponding period, but were still several times higher than in the summerautumn of 2012 (Table 5). The predominant VOCs in all samples were fatty acids whose content ranged from 0.23643 to $127.93500 \mathrm{mg} / \mathrm{g}$ and was characterized by similar seasonal fluctuations as total VOC levels. In 2013, alcohol concentrations in the examined samples were determined at 2.37652 to $4.65645 \mathrm{mg} / \mathrm{g}$ and were significantly higher than in 2014 $(0.63736-1.81126 \mathrm{mg} / \mathrm{g})$ and $2012(0.00841-0.36485 \mathrm{mg} / \mathrm{g})$. Very low levels of total VOCs and fatty acids $\mathrm{C}_{2}-\mathrm{C}_{7}$ were noted in 2012. The contents of aldehydes and esters were also very low in 2012 . Aldehyde levels reached $0.00059 \mathrm{mg} / \mathrm{g}$ in 2012 on average, and they were nearly 65 -fold higher in the remaining seasons at $0.03834 \mathrm{mg} / \mathrm{g}$ on average. Even greater variations were observed in the ester content of cheeses. Ester contents were negligible in 2012, whereas in 2013-2014, they were determined in the range of 0.08507 to $0.24185 \mathrm{mg} / \mathrm{g}$. An opposite trend was noted in ketone levels which were substantially higher in 2012 than in the remaining years. On average, ketone contents were determined at $0.1395 \mathrm{mg} / \mathrm{g}$ in 2012 and at $0.00500 \mathrm{mg} / \mathrm{g}$ in 2013-2014 (Table 5).

The unique flavor of different cheeses can be attributed to both starter and nonstarter bacteria. The sensory attributes of cheese, including flavor, aroma and consistency, are developed during complex interactions between bacteria. The synthesized VOCs play a very important role in this process [Pérès et al., 2001; Mondello et al., 2005; Januszkiewicz et al., 2008]. Volatile organic compounds are produced via three 
A

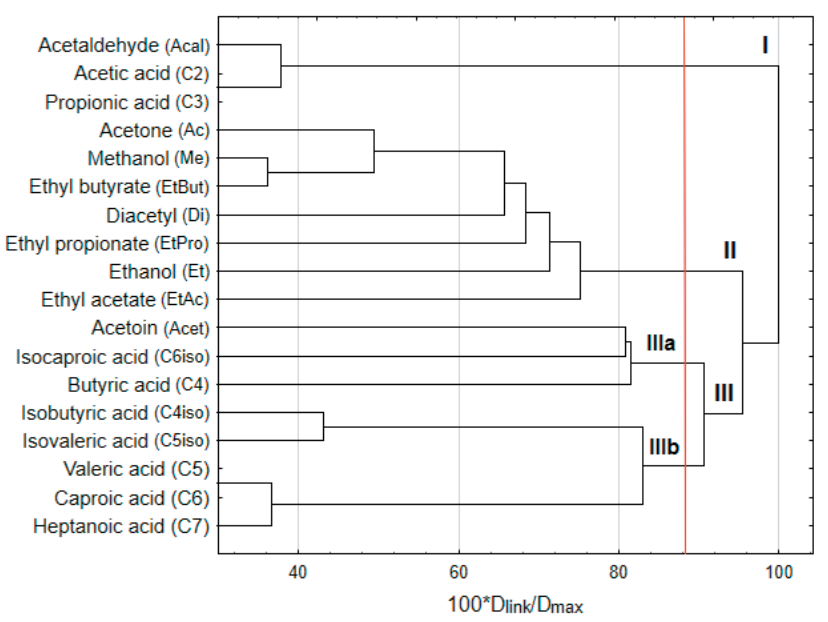

B

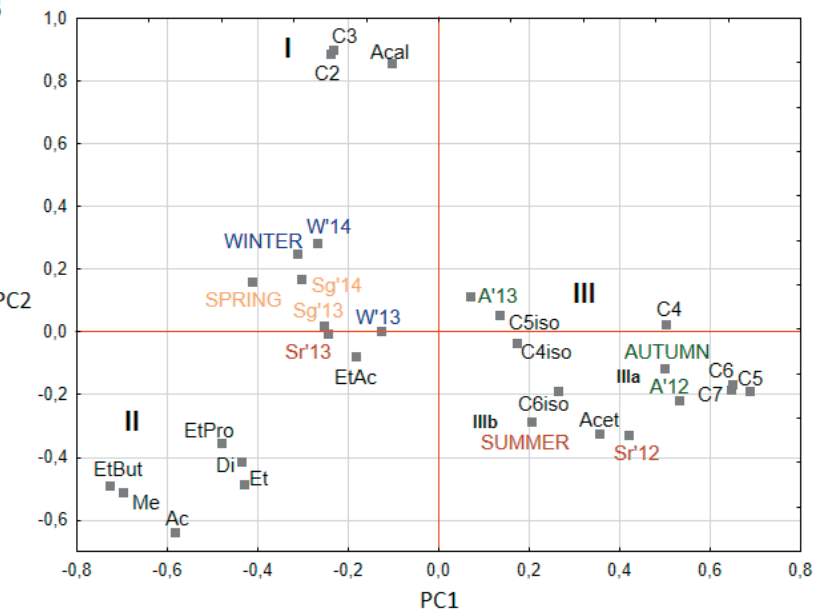

FIGURE 2. A - The dendrogram of a dissimilarity measure between the volatile compounds; B - The Principal Component Analysis biplot of seasonal variables and volatile compounds related to component $1(P C 1)$ and component $2(P C 2)$.

Acal - acetaldehyde; Ketones: Ac - acetone, Di - diacetyl, Acet - acetoin; Alcohols: Me - methanol; Et - ethanol; Esters: EtAc - ethyl acetate, EtPro - ethyl propionate, EtBut - ethyl butyrate; Fatty acids: $\mathrm{C}_{2}$ - acetic acid, $\mathrm{C}_{3}$ - propionic acid, $\mathrm{C}_{4 \text { iso }}-$ isobutyric acid, $\mathrm{C}_{4}-$ butyric acid, $\mathrm{C}_{5 \text { iso }}-$ isovaleric acid, $\mathrm{C}_{5}$ - valeric acid, $\mathrm{C}_{6 \text { iso }}$ - isocaproic acid, $\mathrm{C}_{6}$ - caproic acid; $\mathrm{C}_{7}$ - heptanoic acid.

major catabolic pathways that are involved in flavor development: fermentation (lactose and citrates), lipolysis (milk fat), and proteolysis (casein) [Gobbetti et al., 2015]. During these processes, lactose is converted to diacetyl, acetoin, acetaldehyde, and acetic acid. Fatty acids are converted to ketones, secondary alcohols, esters, and lactones; and casein - to alcohols, aldehydes, acids, esters, and sulfur compounds [Smit et al., 2005]. In this study, HS-GC revealed the presence of all VOC groups in Swiss-Dutch-type cheeses. The presence of alcohols, esters, ketones, short-chain and medium-chain fatty acids was also determined in Serbian Pirotski kačkavalj cheese [Milosavljević et al., 2012] and French Cantal cheese [De Freitas et al., 2007]. According to Pastink et al. [2008], considerable differences in the flavor-forming ability of LAB exist not only between species, but also between strains. The cited authors demonstrated that "wild" LAB strains produced much greater quantities of methyl aldehydes and methyl alcohols than industrial strains. In our study, cheese samples from all seasons of 2013 were abundant in alcohols, in particular methyl alcohol. The prevalence of NSLAB was particularly high in 2013, especially in the summer and autumn. In the cited study concerning Cantal cheese [De Freitas et al., 2007], ethanol was the major VOC. Ethanol is a metabolite of complex processes involving yeast, Leuconostoc, Lactococcus, and thermophilic LAB. Like other alcohols synthesized in cheese, it is not directly responsible for the flavor of cheese, but it determines the production of ethyl esters which are flavor-forming compounds [Thierry et al., 2006]. In our study, ester contents were also higher in cheese samples characterized by a higher alcohol content than in the samples where alcohol levels were low or where alcohol was not detected. Lactate fermentation, amino acid catabolism, and fat lipolysis are sources of free fatty acids in ripened cheese [McSweeney \& Sousa, 2000]. Dolci et al. [2008] demonstrated moderate levels of lipolytic activity in Castelmango cheese containing short-chain fatty acids such as formic acid, acetic acid, propionic acid, butyric acid, valeric acid, and isovaleric acid.
The cited authors attributed their findings to the presence of enterococci, staphylococci, and yeast whose counts were high in all stages of the cheese production process. In another study, the presence of short-chain fatty acids was attributed not only to fecal streptococci, but to all secondary microorganisms [Fox et al., 2004]. In our study, fatty acid contents were several dozen times higher in cheese samples characterized by a higher activity and/or prevalence of both starter and nonstarter bacteria, i.e. in the samples collected between the winter of 2013 and the spring of 2014.

\section{Statistical analysis of VOC profiles}

The seasonal variations in the VOC profiles of SwissDutch-type cheeses produced between 2012 and 2014 were determined by principal component analysis (PCA) which was preceded by hierarchical cluster analysis (HCA) (Figure 2). An HCA dendrogram showed that VOCs were organized in three clusters: I, II and III, with the last one comprising two sub-clusters (IIIa and IIIb), which showed a dissimilarity $>80$ (Figure 2A) and was largely consistent with the results of the PCA (Figure 2B). However, the first (PC 1) and second (PC 2) principal component explained $46.63 \%$ of the total variation. Acetaldehyde (Acal), acetic acid $\left(\mathrm{C}_{2}\right)$, and propionic acid $\left(\mathrm{C}_{3}\right)$ were grouped together in cluster I, since they were variables with the highest negative loading in PC 2 (Figure 2 and Table 6). Cluster II was comprised primarily of acetone (Ac), methanol (Me), and ethyl butyrate (EtBut), since they were variables with moderate negative loading in PC 1 and PC 2. They were also accompanied by weak negative loadings of diacetyl (Di), ethanol (Et), ethyl propionate (EtPro), and ethyl acetate (EtAc). Cluster III was comprised primarily of valeric acid $\left(\mathrm{C}_{5}\right)$, caproic acid $\left(\mathrm{C}_{6}\right)$, and heptanoic acid $\left(\mathrm{C}_{7}\right)$, since they were variables with moderate positive loading in PC 1 and they accompanied by isobutyric acid $\left(\mathrm{C}_{\text {4iso }}\right)$, isovaleric acid $\left(\mathrm{C}_{\text {5iso }}\right)$ (cluster IIIa) as well as acetoin (Acet), isocaproic acid $\left(\mathrm{C}_{6 i s o}\right)$, and butyric acid $\left(\mathrm{C}_{4}\right)$ (cluster IIIb). As demonstrated by Figure 2, the resulting three 


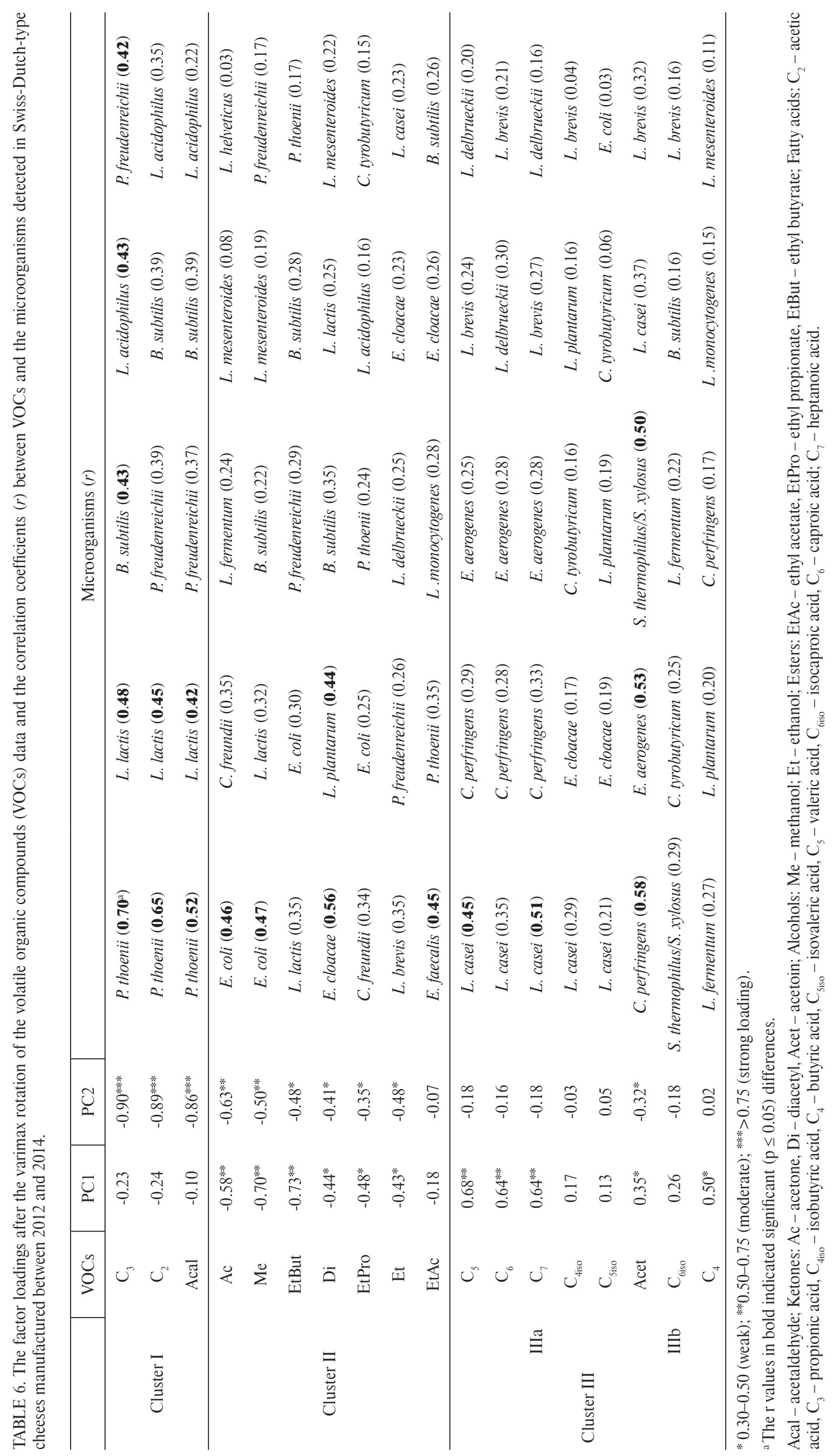


clusters represented a collection of cheeses produced in different years and even seasons. The cheeses manufactured in 2012 were largely characterized by VOCs from cluster III, which were discriminated from the samples of 2013/2014 seasons. Moreover, cluster III contained sub-clusters a and b, which represented collections of samples from the autumn and summer, respectively. In turn, cheeses produced mainly in winter-spring 2013/14 were characterized either by VOCs from cluster I or VOCs from cluster II. Importantly, significant coefficients of correlation ( $r$ ) were calculated for the relationships between $\mathrm{C}_{3}$ vs. P. thoenii (0.70), L. lactis (0.48), L. acidophilus (0.43), B. subtilis (0.43), and P. freudenreichii (0.42); $\mathrm{C}_{2}$ vs. P. thoenii (0.65) and L. lactis (0.45); as well as acetaldehyde (Acal) vs. P. thoenii (0.52) and L. lactis (0.42). The above indicates that these microorganisms contributed to the synthesis of acetaldehyde, $\mathrm{C}_{2}$, and $\mathrm{C}_{3}$ in cheese (Table 6). The prevailing E. coli, E. cloacae, and E. faecalis correlated with $\mathrm{Ac} / \mathrm{Me}, \mathrm{Di}$, and EtAc from cluster II, respectively. Among VOCs from cluster III, $\mathrm{C}_{5}$ and $\mathrm{C}_{7}$ exhibited the highest correlation with $L$. casei and the Acet with $C$. perfringens, E. aerogenes, and $S$. thermophilus/S. xylosus, indicating that they could be considered as important contributors to these VOCs. An analysis of the correlations between VOCs and bacteria revealed that the sensory attributes of SwissDutch-type cheeses were formed primarily by starter bacteria (L. lactis, L. mesenteroides, and P. freudenreichii), whereas nonstarter bacteria exerted strong flavor-forming effects after 52 days of ripening.

The two-year study yielded massive amounts of data (DGGE profiles, VOC profiles, bacterial counts) which were difficult to interpret. Advanced computational methods, such as HCA, PCA or partial least squares (PLS) regression, are increasingly often used in studies of this type. Milosavljević et al. [2012] relied on AHC and PCA to compare contents of VOC determined by different gas chromatography methods. Based on an analysis of GC data, they concluded that the results of AHC and PCA should be analyzed in combination to produce a more comprehensive VOC profile of ripened cheeses. In turn, Mauriello et al. [2003] were able to identify the region of origin of mozzarella cheese based on the results of PCA, whereas Duthoit et al. [2005] also relied on PCA and PLS regression analysis to determine changes in the sensory and microbiological properties of Salers cheese and reported correlations between sensory properties and bacterial cultures. Similarly to our study, they observed that nonstarter bacteria, such as Enterobacteriaceae and Bacillus, were responsible for the texture, flavor, and aroma of cheese.

A combination of culture-dependent and culture-independent methods supported more accurate analyses of the cheese microbiota and its role in the formation of volatile compounds, as well as the identification of bacterial species synthesizing compounds that affect the sensory quality of ripened cheese. Thus, the results of this study indicate that the diversity of bacterial communities and profiles of volatile compounds are highly dependent upon the seasonality of cheese production. For cheese manufacturers, the biodiversity of cheese batches, despite being carried out according to the same technological scheme, is a very important observation. Awareness of these dependencies may contribute to a better understanding of phenomena occurring during the cheese production process, giving the opportunity to prevent technological fluctuations and obtain the final product of excellent quality.

\section{CONCLUSIONS}

The study revealed differences in the composition of microbiota and the content of VOCs in Swiss-Dutch-type cheeses manufactured in different seasons of the year. Therefore, cheese samples were divided into two groups. The first group was composed of cheeses produced in winter-spring (clusters I and II). These samples were characterized by the prevalence of P. thoenii, L. lactis, L. acidophilus, and B. subtilis which were correlated with the contents of acetaldehyde and fatty acids $\mathrm{C}_{2}$ and $\mathrm{C}_{3}$, whereas E. coli, E. cloacae, and L. plantarum increased contents of methanol, acetone, and diacetyl. The second group was composed of cheeses produced in summerautumn (cluster III). It was characterized by the prevalence of NSLAB (including L. casei, L. fermentum, and L. brevis) which increased the content of fatty acids $\mathrm{C}_{4}{ }^{-} \mathrm{C}_{7}$, as well as C. perfringens, E. aerogenes, and S. thermophilus/S. xylosus which probably increased the content of acetoin. The observations made in this study do not exhaust the possibilities of this approach, but indicate that the described methods can be effectively used to control the cheese production process and to monitor microbiological contamination.

\section{ACKNOWLEDGEMENTS}

We are grateful to Dr. Marta Mikš for calibration of the gas chromatograph for quantitative identification volatile compounds of microbiological origin in samples of milk and ripened chees.

\section{RESEARCH FUNDING}

This study was supported by the National Science Center, Poland (grant no. N N312 484140) and by University of Warmia and Mazury in Olsztyn (17.610.015-300).

\section{CONFLICT OF INTEREST}

The authors declare that they have no conflict of interest.

\section{REFERENCES}

1. Abriouel, H., Martin-Platero, A., Maqueda, M., Valdivia, E., Martinez-Bueno, M. (2008). Biodiversity of the microbial community in Spanish farmhouse cheese as revealed by culture-dependent and culture-independent methods. International Journal of Food Microbiology, 127(3), 200-208.

2. Alegría, A., Alvarez-Martin, P., Sacristan, N., Fernandez, E., Delgado, S., Mayo, B. (2009). Diversity and evolution of the microbial populations during manufacture and ripening of Casin, a traditional Spanish, starter-free cheese made from cow's milk. International Journal of Food Microbiology, 136(1), 44-51.

3. AOAC International 2005. Method 926.08. Official Methods of Analysis. 18th ed. AOAC International, Gaithersburg, MD, USA: AOAC International; 2005. 
4. Ayad, E.H.E., Verheul, A., De Jong, C., Wouters, J.T.M., Smit, G (1999). Flavour forming abilities and amino acid requirements of Lactococcus lactis strains isolated from artisanal and nondairy origin. International Dairy Journal, 9, 725-735.

5. Caridi, A., Micari, P., Caparra, P., Cufari, A., Sarullo, V. (2003). Ripening and seasonal changes in microbial groups and in physico-chemical properties of the ewes' cheese Pecorino del Poro. International Dairy Journal, 13, 191-200.

6. De Freitas, I., Pinon, N., Thierry, A., Lopez, C., Maubois, J.-L., Lortal, S. (2007). In depth dynamic characterization of French POD Cantal cheese made from raw milk. Le Lait, 87, 97-117.

7. Dolci, P., Alessandria, V., Rantsiou, K., Rolle, L., Zeppa, G., Cocolin, L. (2008). Microbial dynamics of Castelmagno PDO, a traditional Italian cheese, with a focus on lactic acid bacteria ecology. International Journal of Food Microbiology, 122(3), 302-311.

8. Drinan, F.D., Cogan, T.M. (1992). Detection of propionibacteria in cheese. Journal of Dairy Research, 59(1), 65-69.

9. Duru, I.C., Laine, P., Andreevskaya, M., Paulin, L., Kananen, S., Tynkkynen, S., Auvinen, P., Smolander O.-P. (2018). Metagenomic and metatranscriptomic analysis of the microbial community in Swiss-type Maasdam cheese during ripening. International Journal of Food Microbiology, 281, 10-22.

10. Duthoit, F., Callon, C., Tessier, L., Montel, M.-C. (2005). Relationships between sensorial characteristics and microbial dynamics in "Registered Designation of Origin" Salers cheese. International Journal of Food Microbiology, 103(3), 259-270.

11. Ercolini, D., Moschetti, G., Blagiotta, G., Coppola, S. (2001). The potential of a polyphasic PCR-DGGE approach in evaluating microbial diversity of natural whey cultures for water-buffalo Mozzarella cheese production: bias of culture-dependent and culture-independent analyses. Systematic and Applied Microbiology, 24(4), 610-617.

12. Felicio T.L., Esmerino E.A., Vidal V.A.S., Cappato L.P., Garcia R.K.A., Cavalcanti R.N., Freitas M.Q., Conte Juniord C.A., Padilha M.C., Silva M.C., Raices R.S.L., Arellano D.B., Bollini H.M.A., Pollonio M.A.R., Cruz A.G. (2016). Physico-chemical changes during storage and sensory acceptance of low sodium probiotic Minas cheese added with arginine. Food Chemistry, 196, 628-637.

13. Flórez, A.B., Mayo, B. (2006). PCR-DGGE as a tool for characterizing dominant microbial populations in the Spanish blueveined Cabrales cheese. International Dairy Journal, 16, 12051210 .

14. Fox, P.F., McSweeney, P.L.H., Cogan, T.M., Guinee, T.P. (2004). Cheese: Chemistry, Physics and Microbiology. 3nd edition, Elsevier Ltd., London, UK.

15. Franciosi, E., Settanni, L., Cavazza, A., Poznanski, E. (2009). Biodiversity and technological potential of wild lactic acid bacteria from raw cows' milk. International Dairy Journal, 19, 3-11.

16. Frece, J., Vrdoljak, M., Filipčić, M., Jelić, M., Čanak, I., Jakopović, Ž., Pleadin, J., Gobin, I., Landeka Dragičević, T., Markov, K. (2016). Microbiological quality and variability of natural microbiota in Croatian cheese maturing in lambskin sacks. Food Technology and Biotechnology, 54(2), 129-134.

17. Gala, E., Landi, S., Solieri, L., Nocetti, M., Pulvirenti, A., Giudici, P. (2008). Diversity of lactic acid bacteria population in ripened Parmigiano Reggiano cheese. International Journal of Food Microbiology, 125(3), 347-351.
18. Gobbetti, M., De Angelis, M., Di Cagno, R., Mancini, L., Fox, P.F. (2015). Pros and cons for using non-starter lactic acid bacteria (NSLAB) as secondary/adjunct starters for cheese ripening. Trends in Food Science and Technology, 45(2), 167-178.

19. Granato D., Putnik P., Bursać Kovačević D., Sousa Santos J., Calado V., Silva Rocha R., Gomes Da Cruz A., Jarvis B., Ye Rodionova O., Pomerantsev A. (2018). Trends in chemometrics: Food authentication, microbiology, and effects of processing. Comprehensive Review in Food Science and Food Safety, 17(3), 663-677.

20. IDF 222: 2008. ISO 3433:2008. Cheese - determination of fat content - Van Gulik method. International Standard Organization; 2008.

21. IDF 88:2006. ISO 5943:2006. Cheese and processed cheese products - Determination of chloride content -- Potentiometric titration method. International Standard Organization; 2006.

22. IDF 50:2008. ISO 707:2008. Milk and milk products - Guidance on sampling; International Standard Organization; 2008.

23. Januszkiewicz, J., Sabik, H., Azarnia, S., Lee, B. (2008). Optimization of headspace solid-phase microextraction for the analysis of specific flavors in enzyme modified and natural cheddar cheese using factorial design and response surface methodology. Journal of Chromatography A, 1195(1-2), 16-24.

24. Johnson, M.E. (2017). A 100-Year Review: Cheese production and quality. Journal of Dairy Science, 100(12), 9952-9965.

25. Jordan, K.N., Cogan, T.M. (1993). Identification and growth of non-starter lactic acid bacteria in Irish cheddar cheese. Irish Journal of Agricultural and Food Research, 32, 47-55.

26. Joux, F., Lebaron, P. (2000). Use of fluorescent probes to assess physiological functions of bacteria at single-cell level. Microbes and Infection, 2(12), 1523-1535.

27. Klijn, N., Nieuwenhof, F.F.J., Hoolwerf, J.D., van der Waals, C.B., Weerkamp, A.H. (1995). Identification of Clostridium tyrobutyricum as the causative agent of late blowing in cheese by species-specific PCR amplification. Applied and Environmental Microbiology, 61, 2919-2924.

28. Lindberg, A.-M., Christiansson, A., Rukke, E.-O., Eklund, T., Molin, G. (1996). Bacterial flora of Norwegian and Swedish semi-hard cheese after ripening, with special reference to Lactobacillus. Netherlands Milk and Dairy Journal, 50, 563-572.

29. Mangia, N.P., Fancello, F., Deiana, P. (2016). Microbiological characterization using combined culture dependent and independent approaches of Casizolu pasta filata cheese. Journal of Applied Microbiology, 120, 329-345.

30. Marino, M., Maifreni, M., Rondinini, G. (2003). Microbiological characterization of artisanal Montasio cheese: analysis of its indigenous lactic acid bacteria. FEMS Microbiology Letters, 229, 133-140.

31. Mauriello, G., Moio, L., Genovese, A., Ercolini, D. (2003). Relationships between flavoring capabilities, bacterial composition, and geographical origin of natural whey cultures used for traditional water-buffalo Mozzarella cheese manufacture. Journal Dairy Science, 86, 486-497.

32. McSweeney, P.L.H., Sousa, M.J. (2000). Biochemical pathways for the production for flavour compounds in cheese in during ripening: a review. Le Lait, 80(3), 293-324.

33. Milosavljević, N.P., Blagojević, P.D., Savić, D.S., Radulović, N.S. (2012). Application of HS-SPME-GC-MS-derived variables for monitoring ripening-induced changes in cheese volatile compounds. Dairy Science Technology, 92(4), 321-333. 
34. Mondello, L., Costa, R., Tranchid, P.Q., Chiofalo, B., Zumbo, A., Dugo, P., Dugo, G. (2005) Determination of flavour components in Sicilian goat cheese by automated HS-SPME-GC. Flavour and Fragrance Journal, 20(6), 659-665.

35. Nalepa, B., Markiewicz, L.H. (2017). PCR-DGGE markers for qualitative profiling of microbiota in raw milk and ripened cheeses. LWT - Food Science and Technology, 84, 168-174.

36. Ogier, J.-C., Lafarge, V., Girard, V., Rault, A., Maladen, V., Gruss, A., Leveau, J.-Y., Delacroix-Buchet, A. (2004). Molecular fingerprinting of dairy microbial ecosystems by use of temporal temperature and denaturing gradient gel electrophoresis. Applied and Environmental Microbiology, 70(9), 5628-5643.

37. Pastink, M.I., Sieuwerts, S., de Bok, F.A.M., Janssen, P.W.M., Teusink, B., van Hylckman Vlieg, J.E.T., Hugenholtz, J. (2008). Genomics and high-throughput screening approaches for optimal flavor production in dairy fermentation. International of Dairy Journal, 18(8), 781-789.

38. Pérès, C., Viallon, C., Berdague, J.-L. (2001). Solid-phase microextraction-mass spectrometry: a new approach to the rapid characterization of cheeses. Annals of Chemistry, 73, 1030-1036.

39. Porcellato, D., Skeie, S.B. (2016). Bacterial dynamics and functional analysis of microbial metagenomes during ripening of Dutch-type cheese. International Dairy Journal, 61, 182-188.

40. Randazzo, C.L., Pitino, I., Ribbera, A., Caggia. C. (2010). Pecorino Crotonese cheese: Study of bacterial population and flavour compounds. Food Microbiology, 27(3), 363-374.

41. Randazzo, C.L., Vaughan, E.E., Caggia, C. (2006). Artisanal and experimental Pecorino Siciliano cheese: Microbial dynamics during manufacture assessed by culturing and PCR-DGGE analyses. International Journal of Food Microbiology, 109(1-2), 1-8.

42. Rehfeld I.S., Fraiha A.L.S., Matos A.C.D., Guedes M.I.M.C., Costa E.A., de Souza M.R., Cavalcante L.F.L., Lobato Z.I.P. (2017). Survival of Vaccinia virus in inoculated cheeses during 60-day ripening. Journal of Dairy Science 100(9), 7051-7054.
43. Ricciardi, A., Guidone, A., Ianniello, R.G., Cioffi, S., Aponte, M., Pavlidis, D., Tsakalidou, E., Zotta, T., Parente, E. (2015). A survey of non-starter lactic acid bacteria in traditional cheeses: Culture dependent identification and survival to simulated gastrointestinal transit. International Dairy Journal, 43, 42-50.

44. Santiago-López, L., Aguilar-Toalá, J.E., Hernández-Mendoza, A., Vallejo-Cordoba, B., Liceaga, A.M., González-Córdova, A.F. (2018). Bioactive compounds produced during cheese ripening and health effects associated with aged cheese consumption. Journal of Dairy Science, 101 (5), 3742-3757.

45. Sienkiewicz, J. (2010). Concepts of biodiversity - their dimensions and measurements in the light of the subject literature. Ochrona Środowiska i Zasobów Naturalnych, 45, 7-29 (in Polish).

46. Skelin, A., Mrkonjić Fuka, M., Čanžek Majhenič, A., Redžepović, S., Samaržija, D., Bogovič Matijašić, B. (2012). Phenotypic and genotypic characterization of indigenous Lactobacillus community from traditional Istrian ewe's cheese. Food Technology and Biotechnology, 50(3), 362-370.

47. Smit, G., Smit, B.A., Engel, W.J.M. (2005). Flavour formation by lactic acid bacteria and biochemical flavour profiling of cheese products. FEMS Microbiology Reviews, 29, 591-610.

48. Terzaghi, B.E., Sandine, W.E. (1975). Improved medium for lactic streptococci and their bacteriophages. Applied Microbiology, 29, 807-813.

49. Thierry, A., Maillard, M.B., Richoux, R., Lortal, S. (2006). Ethyl ester formation is enhanced by ethanol addition in mini Swiss cheese with and without added propionibacteria. Journal of Agricultural and Food Chemistry, 54(18), 6819-6824.

Submitted: 13 February 2019. Revised: 15 May 2019. Accepted: 6 June 2019. Published on-line: 3 July 2019. 